\title{
Key Drivers of Public Debt Levels: Empirical Evidence from Africa
}

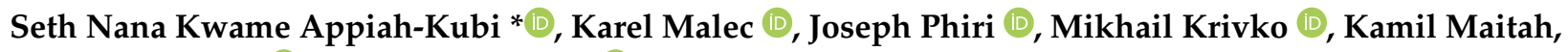 \\ Mansoor Maitah (D) and Luboš Smutka (D)
}

check for

updates

Citation: Appiah-Kubi, S.N.K.;

Malec, K.; Phiri, J.; Krivko, M.;

Maitah, K.; Maitah, M.; Smutka, L. Key Drivers of Public Debt Levels: Empirical Evidence from Africa. Sustainability 2022, 14, 1220.

https://doi.org/10.3390/

su14031220

Academic Editors: Pompeo Della Posta, Enrico Marelli and Marcello Signorelli

Received: 29 November 2021

Accepted: 20 January 2022

Published: 21 January 2022

Publisher's Note: MDPI stays neutral with regard to jurisdictional claims in published maps and institutional affiliations.

Copyright: () 2022 by the authors Licensee MDPI, Basel, Switzerland. This article is an open access article distributed under the terms and conditions of the Creative Commons Attribution (CC BY) license (https:// creativecommons.org/licenses/by/ $4.0 /)$.
Department of Economics, Faculty of Economics and Management, Czech University of Life Sciences in Prague, 16500 Prague, Czech Republic; maleck@pef.czu.cz (K.M.); phiri@pef.czu.cz (J.P.); krivko@pef.czu.cz (M.K.); maitahk@pef.czu.cz (K.M.); maitah@pef.czu.cz (M.M.); smutka@pef.czu.cz (L.S.)

* Correspondence: appiah-kubi@pef.czu.cz; Tel.: +420-608-399-941

\begin{abstract}
The rising public debt level in Africa and the sustainability of that debt remains an important research agenda. As such, understanding the factors that impact the rising public debt level in Africa remains an important research agenda. Our paper investigates the key determining drivers that have a direct and indirect impact on the rising level of public debt in Africa from a panel of 47 African nations for the period 2000-2018. Using the generalized method of moments (GMM) and fixed effects two-stage least squares (IV-FE) methodological approach the study confirms that a rise in the corruption level leads to an increase in the public debt in Africa. Our findings additionally indicate that government investment enhances the positive and significant association with public debt levels in the sampled countries. Our result revealed that government consumption and tax revenue have a significant negative relationship with the levels of public debt in Africa. Lastly, our results showed that military expenditure has a positive but insignificant relationship with public debt levels in Africa. In terms of policy recommendation, the study suggests African countries should intensify the fight against corruption and strengthen political and governance institutions that will help reduce public debt levels and promote economic growth and development.
\end{abstract}

Keywords: corruption; public debt; government investment; government consumption; military expenditure; tax revenue

\section{Introduction}

Each country aims to achieve economic development. As a result of this, countries are implementing projects that will support economic development. The goal of achieving economic stability and development must finance essential sectors of the economy to propel growth [1,2]. Usually, these sectors are unviable for private investors to venture because of the high initial outlay involved [3]. Nevertheless, when governments invest in these key sectors, it boosts both domestic and foreign investors' confidence to also venture into these businesses [4]. These sectors include education, health, agriculture, sanitation, technology, infrastructure, and many others [5,6].

According to Serven and Solimano [7], considering the huge initial capital needed to undertake this development agenda, governments usually run into deficits since government revenue generated from taxes, charges fees from publicly provided goods and services, profits from state enterprises and seignories from the central bank among others are insufficient.

Governments usually rely on borrowing to bridge the financing gap, especially in the case of developing countries [8-10]. The act of government borrowing externally or domestically from institutions, countries and individuals encapsulates the concept of public debt. The main principle rooting this credit facility is that, eventually, gains from these projects will cover the debt incurred [11]. 
According to Burhanuddin et al. [12], public debt plays an important and integral role in every economy. Public debt as a means of finance enables countries to finance their public expenditure which improves social welfare and encourages economic growth and development through capital accumulation. In addition, developing countries who face the constraint of insufficient stock of capital can access capital to undertake investment opportunities that hitherto would not have been possible [13,14]. Furthermore, according to Belguith and Omrane [15], public debt plays a role in promoting financial safety by stabilizing the financial sector. Again, fiscal authorities can play their part in stimulating economic growth by stabilizing the economy [16].

Unarguably, public debt is an integral part of the development journey of every country. However, like a double-edged sword, overborrowing and imprudent allocation of borrowed funds can lead to debt overhang which is detrimental to economic growth [9,17-19]. Several studies have been done to determine the debt threshold that when surpassed by African countries' debt, is associated to negative economic growth. Mensah et al. [20] found that debt beyond 50-80 percent of GDP harms economic growth. Ndoricimpa [21] also set the debt threshold to range between 58-63 percent of GDP. These studies confirm the threshold of 60 percent conducted by the African Monetary Co-operation Program (AMCP).

Figure 1 below shows the growth of the public debt to GDP of Africa relative to other regions in the world from 2000 to 2019. From the diagram, Africa had a high debt level of approximately 68 percent during the early years of 2000. This high debt level can be traced back to 1970 [22]. In recent times, public debt levels in Africa are rising again, placing the continent as the third most heavily indebted region comparative to other regions. The increasing growth of public debt level in 2019 has crossed the 50 percent threshold, which is an alarming signal that the fast growth in the public debt levels in Africa can again surpass the highest public debt levels-to-GDP in the world, which can cause another debt crisis.

Africa public debt growth relative to other regions

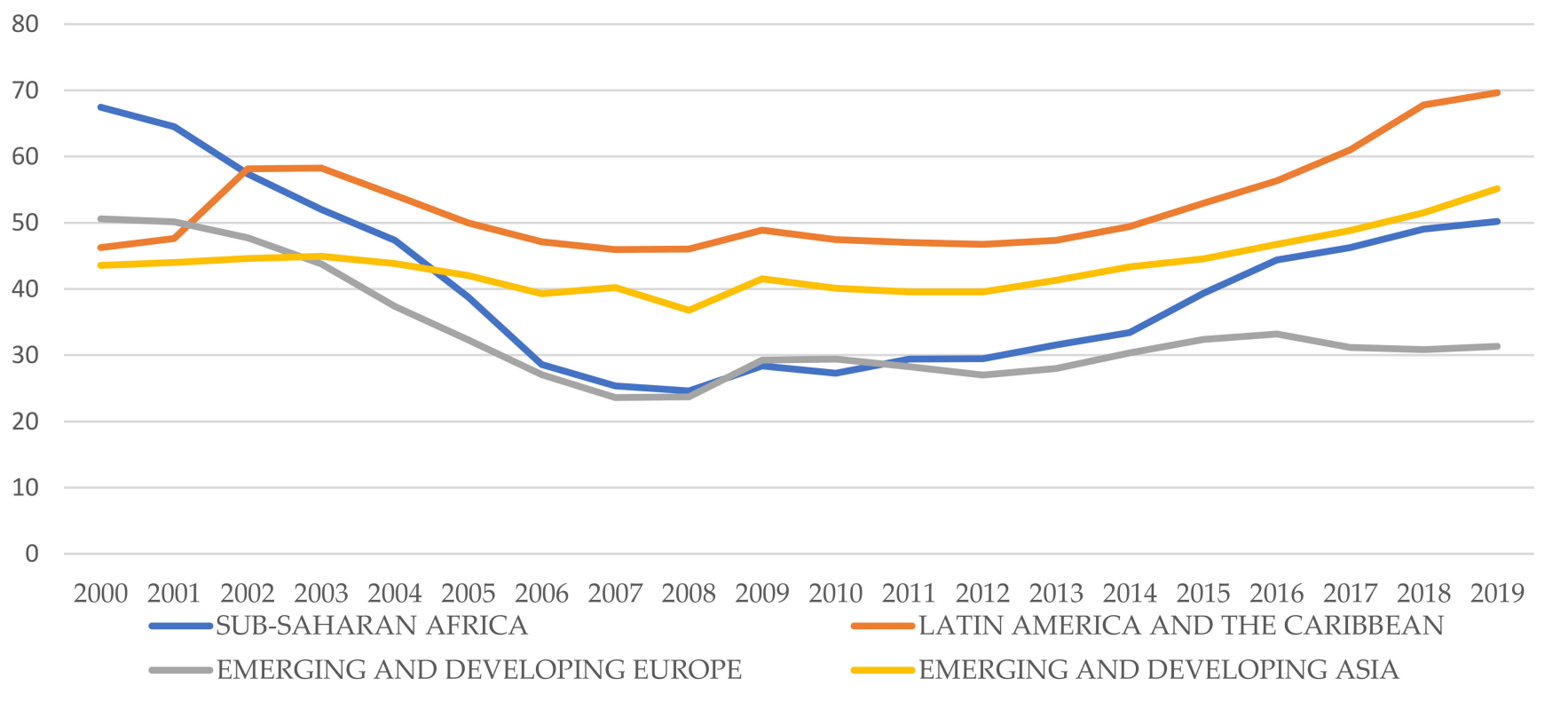

Figure 1. Trends in Public debt levels across the world regions sourced from the World Bank World Development Indicators (WDI), World Competitiveness Index report, Worldwide Governance Indicators database and World Economic Outlook database (2000-2019).

It is therefore not surprising that Africa was faced with a devastating debt crisis during those periods $[15,23,24]$. Through the intervention of debt relief initiatives by the IMF and 
the World Bank, most African countries enjoyed outright debt forgiveness, causing the public debt level in the region to fall [25].

Considering that debt financing is inevitable, and debt overhang is problematic in Africa, it is necessary to know the key drivers of the debt buildup. As government expenditure increases relative to government revenue, the budget deficit increases therefore requiring the government to borrow more [25-27]. Governments in Africa are trying to reduce the increase in public debt by using a contractionary fiscal policy and improving the efficiency of the tax system to increase their revenue and reduce the budget deficit $[8,15,16]$.

According to Transparency International [28], out of a total of 176 countries covered by the report, most African countries scored below 50, making the continent the most corrupt and with the highest public debt levels in the world; thus, it is imperative to research the key drivers of public debt levels in Africa. To provide a guide to African governments in their policy formulation and implementation in this respect, an empirical study that examines the key drivers of public debt levels in Africa is very important, and our study looks to attain this.

Therefore, the main aim of our study was to explore the key determining drivers that have a direct and indirect influence on the rising level of public debt in Africa within the period 2000-2018. Our results will complement existing knowledge on the determining factors of public debt levels in Africa, which remain scant.

In specific terms, our study would seek to provide answers to five research questions: (a) Does corruption impact the public debt levels in Africa? (b) Does government investment contribute to the increasing levels of public debt in Africa? (c) Is government consumption a determining factor of public debt levels in Africa? (d) Is military expenditure a driver of public debt in Africa? (e) Does tax revenue have an impact on public debt in Africa?

Cooray et al. [13] examined the effect of corruption and public debt using a panel of 126 countries from 1996 to 2012 and found that corruption adversely impacts public debt. Apergis and Apergis [29] extended the study of Cooray et al. [13] to investigate the linkage between corruption and government arrears through a regime-based approach. Using a sample of 120 countries from 1999 to 2015 and the Panel Smooth Transition Regression (PSTR) methodological approach, the study found that public debt levels are higher in high corruption regimes compared to low corruption regimes. According to Transparency International [28] and Hannes [30], out of a total of 176 countries covered by the report, most African countries scored below 50, making the continent most corrupt in the world. However, the consequences of corruption on the public debt in Africa remain unclear. With this motivation, our paper seeks to answer the question: 'Does corruption have an impact on the public debt levels in Africa?'.

An increase in public investment generally increases government expenditure, therefore, initially, public debt should increase [31,32]. However, depending on the level of private individuals' participation in capital formation, the above hypothesis may not hold. This is because as private investors venture into road construction, school building and other capital formation projects, it reduces the burden on the government by reducing government expenditure. As this happens, it is likely to lower the government budget deficit $[15,33]$. With this motivation, our paper seeks to answer our second question: 'Does government investment contribute to the increasing levels of public debt in Africa?'.

Swampy [31] and Liu and Mikesell [34] also used general government final consumption as a proxy for government consumption. For this study, the natural log of government consumption is used. A diverse relationship between government consumption and public debt has been established in the literature. Swampy [31] found in his studies that a rise in government consumption results in a high public debt level. Findings from Al-Qudah [35] also indicated a negative and noteworthy association between public debt and government consumption, meaning government spending on consumption decreases public debt level; however, Liu and Mikesell [34] posit that government spending on consumption has an 
insignificant impact on public debt levels. This results in our third research query: 'Is government consumption a determining factor of public debt levels in Africa?'.

Indisputably, security is a basic requirement for every country, therefore the government would have to spend on it. Spending on the military by acquiring arms and other important equipment increases government expenditure, thus increase in borrowing. Studies such as Smyth and Narayan [36], Pateologou [37], Gargouri and Ksantini [38], Cooray et al. [13], Caruso and Di Domizio [39] and Cooray and Schneider [40] also used this proxy for military expenditure. For this reason, Smyth and Narayan [36], Pateologou [37], Gargouri and Ksantini [38] and Caruso and Di Domizio [39] reported a positive relationship between military expenditure and government debt. With this motivation, our paper seeks to answer the fourth research question: 'Is military expenditure a driver of public debt in Africa?'.

According to Appiah-Kubi [16] and Shleifer and Vishny [41], revenue from tax is a way of reducing the tax load of economies. Thus, the ability of governments to generate revenue from tax could aid to reduce the debt burden. Appiah-Kubi [20] and Shleifer and Vishny [41], also conclude that a rise in direct and indirect taxation, a rise in contributions of social security could lead to the lower quality of state institutions and the lower the tax morale of their citizens. With this motivation, our paper seeks to answer the fifth research question: 'Does tax revenue have an impact on public debt in Africa?'.

Several questions on the issue of public debt levels management, drivers of public debt and debt sustainability in Africa have been raised by the International Monetary Fund (IMF) and the World Bank with other bilateral organizations. The results of about thirty-three (33) countries in Africa that have been declared as Highly Indebted Poor Countries (HIPC) and had to be relieved of their debt by these organizations [21,22]. The factsheet by the IMF shows that African countries could not achieve most of their MDGs even after the debt relief packages [28]. Our study comes in time to address the threshold impact of the key drivers of public debt levels of African countries to avoid unnecessary austerity measures that could be detrimental to African economies.

Though borrowing is good, it comes with the implication that, if care is not taken, the rate of the public debt levels will keep on rising. It has therefore become a major concern for policy makers and academicians to pay very close attention to the debt composition of African countries and the key drivers of such debts. It is, however, important to study public debt and find ways to help manage public debt build up. Thus, it is vital to study the key determining drivers that have a direct and indirect influence on the rising level of the public debt in Africa.

Our study proceeds as follows: the second section discusses the empirical literature review related to the determinants of public debt. The third section focuses on the research data and methodology. The fourth section concentrates on the results and discussion. The final part of our research presents conclusions, recommendations and limitations.

\section{Empirical Literature Review}

The assessment of empirical literature on the subject relating to the key determinants of public debts levels is very important for our study. A such, this section seeks to review other scholarly works done on economic determinants of public debt and governance and institutional determinants of public debt. The section would be discussed based on the economic and governance variables conducted by other studies that have an impact on the public debt levels.

\subsection{Economic Determinants of Public Debt}

Extant studies have been done to determine economic factors that influence the level of public debt.

Waheed [42] studied the factors of public debt in both oil and gas importing and exporting countries. The study used panel data of 12 exporting and 12 importing oil and gas countries from the period 2004-2013. The results show that factors that affect debt 
levels in oil and gas importing countries differ from that of exporting oil and gas countries. Factors including trade deficit, international oil prices, interest paid on external debt, FDI and domestic investment have a noteworthy positive association with public debt meaning that an increase in these economic factors will cause debt buildup. However, high GDP growth, general government revenue and gross domestic savings reduce the debt level in oil and gas importing countries. Unlike importing countries, an increase in oil price and domestic investment leads to reducing public debt while government expenditure and inflation accumulate debt in oil and gas exporting countries.

In determining the factors that drive public debt levels in Europe, Gargouri and Ksantini [38] sampled 12 European countries from 2000 to 2014. Using the correlated panels corrected standard error estimation, the results report that, military expenditure, imports and bank non-performing loans positively impact public debt whilst gross domestic product growth and bank liquidity reserves have a negative but significant influence on the public debt level.

Swamy [31] also researched the factors of government debt in developing countries, advanced countries, emerging markets and OECD countries. The study sampled data from the period of 1980 to 2009 via fixed effects and the system generalized method of moments (GMM) in analyzing the data. The findings of the study show that foreign direct investment (FDI), real GDP growth, inflation, government expenditure and population growth negatively influence public debt, while government consumption expenditure, government investment expenditure and trade openness have a positive and significant influence on public debt.

To understand the factors of public debt in Romania, a study was carried out by Pirtea et al. [23] for the period 2000 to 2011. With public debt to GDP ratio as the dependent variable, the study's findings suggest that an increase in real GDP growth and FDI translates into lower public debt, while budget deficit, foreign exchange rate against and real interest rate have a noteworthy positive influence on public debt.

Bittencourt [43] sampled nine South American countries to determine the driving factors of government debt using pooled OLS, fixed effects instrumental variables, the system and difference generalized method of moment and fixed effect methodology from 1970 to 2007. The study regression results indicate that increased economic growth significantly reduces public debt accumulation in South America. The results suggest that gross domestic product has a negative and significant influence on the debt.

Mah et al. [8] researched the influence government spending has on public debt in Greece. The study used the vector correction model and Granger causality model in analysis for the study period between 1975 and 2012. The authors found that government spending has a positive and noteworthy influence on the public debt in Greece, meaning that high government expenditure results in high level of public debt.

Sinha et al. [44] also investigated the influence of inflation, foreign direct investment, current account balance, interest rate, government expenditure, population and real GDP growth on public debt in middle-income and high-income nations. A total of 31 countries were used for the study. The study period for high-income earning countries was from 1993 to 2008 and from 1980 to 2008 for middle-income economies. Both the fixed-effects model and the random-effects model were used in the analysis. The results show that current account balance, education expenditure, government expenditure, and GDP growth rate influence the public debt level in both high-income and middle-income countries. The results again suggest that FDI and inflation rate are insignificant drivers of public debt in developed countries but are determinants for public debt in middle-income economies.

Al-Qudah [35] examined the effect of some macroeconomic variables on public debt in Jordan. These variables include real gross domestic product growth, budget deficit, government current expenditure and unemployment rate. The study was conducted from 1992-2017. The hypothesis of the study was analyzed using autoregressive distributive lag (ARDL). Similar to prior studies, real gross domestic product growth has a negative and noteworthy influence on public debt, but unemployment and budget deficit rate have a 
positive and noteworthy influence on public debt. In the case of Jordan, the government's current expenditure is insignificant in determining public debt level.

Gokmenoglu and Rafik [45] investigate the drivers of Malaysia's external debt using annual data for the period of 1970 to 2013. The authors performed the Johansen cointegration test, vector error correction model (VECM) and Granger causality test in analysis. The results indicate that there is a long-running relationship between external debt and the GDP and recurrent and capital expenditure. The findings indicate that high GDP growth reduces the external debt problem. In contrast, capital and recurrent expenditures increases debt level.

\subsection{Governance and Institutional Determinants of Public Debt}

Governance cannot be ignored when it comes to public debt accumulation. Cooray et al. [13] examined the effect of corruption and public debt using a panel of 126 countries from 1996 to 2012 and found that corruption adversely impacts public debt.

Apergis and Apergis [29] extended the study of Cooray et al. [13] to investigate the linkage between corruption and government arrears through a regime-based approach. Using a sample of 120 countries from 1999 to 2015 and the Panel Smooth Transition Regression (PSTR) methodological approach, the study found that public debt levels are higher in high corruption regimes compared to low corruption regimes. According to Transparency International [28] and Hannes [30], out of a total of 176 countries covered by the report, most African countries scored below 50 making the continent most corrupt in the world.

Meon and Sekkat [46] assessed the impact of quality of governance on growth and investment for a sample of 71 countries from 1970 to 1998. Using a cross-country regression analysis, the study revealed that low levels of government effectiveness, political stability and rule of law magnify the adverse effect of bribery in businesses and national investment. Consequently, government revenue is reduced, increasing budget deficit and leading to public debt accumulation.

According to Appiah-Kubi [16] and Shleifer and Vishny [41], revenue from tax is a way of reducing the tax load of economies. Thus, the ability of governments to generate revenue from tax could aid in reducing the debt burden. Appiah-Kubi [20] and Shleifer and Vishny [41], also conclude that a rise in direct and indirect taxation and a rise in contributions of social security could lead to a lower quality of state institutions and lower the tax morale of their citizens.

Jackson et al. [47] also found that a shadow economy promotes tax evasion, lowers the quality of public services and reduces government ability to provide public goods. They concluded with a sample of 69 countries that the existence of an underground economy decreases tax revenue generated by the government and consequently the government is forced to borrow more.

An empirical review of previous studies revealed that public debt levels have been focused mainly in Asian and European countries and there were few or scant studies on the key determinants or drivers of public debt specifically in Africa. A major controversy in the existing literature has to do with inconsistencies associated with finding a uniform threshold value for several economies. Some studies are of the view that the debt limit is specific to a country and cannot be measured collectively $[8,23]$. As such, our study bridges the gap by estimating a threshold model to investigate the key drivers of public debt levels in Africa. The reviewed studies used different techniques ranging from multiple linear regression and analysis of panel data using a fixed-effects model and a random effect model. Previous studies have revealed that the real growth rate of GDP, budget surplus, population growth and public investment have a negative impact while economic openness, exchange rate, interest rate and capital formation have positive effects on public debt. Our study sought to investigate the impact of corruption, government investment, government consumption, tax revenue, exchange rate, inflation, military expenditure and GDP on public debt levels in Africa from 2000-2018. The main independent variables include 
corruption, government investment, government consumption, military expenditure and tax revenue. Our control variables include exchange rate, inflation and GDP.

\section{The Baseline Data and Model}

\subsection{Baseline Data}

We utilized panel data from forty-seven (47) countries from 2000-2018 to attain our research goal and respond to our study inquiries. The sampled African countries for our study included Algeria, Angola, Benin, Botswana, Burkina Faso, Burundi, Cabo Verde, Cameroon, Central African Republic (CAR), Chad, Comoros, Congo (the Democratic Republic of the), Congo (Republic of the), Cote d'Ivoire, Egypt, Eswatini, Ethiopia, Gabon, Gambia, Ghana, Guinea, Guinea-Bissau, Kenya, Lesotho, Liberia, Madagascar, Malawi, Mali, Mauritania, Mauritius, Morocco, Mozambique, Namibia, Niger, Nigeria, Rwanda, Senegal, Seychelles, Sierra Leone, South Africa, Sudan, Tanzania, Togo, Tunisia, Uganda, Zambia and Zimbabwe. Our sample size was largely due to information availability. Countries for which many data series were not available are excluded from the study to prevent survival bias [30].

Table 1 below shows our data were sourced from several sets of country classifications recorded by the World Development Indicators (WDI), United Nations Conference on Trade and Development (UNCTAD), World Competitiveness Index Report, Worldwide Governance Indicators database and World Resource Institute from 2000-2018. The data of Public Debt (PBDT) as the dependent variable were sourced from the World Economic Outlook database. The independent variables selected as key drivers of public debt levels in Africa include Corruption (CORR), Government Investment (GOVNI), Government Consumption (GOVC), Military Expenditure (MEX) and Tax Revenue (TAXR). The study controlled three economic variables in the regression for country-level economic traits which include Exchange Rate (EXCHR), Gross Domestic Product (GDP) and Inflation (INFL).

Table 1. The Variable Descriptions and Data Sources.

\begin{tabular}{|c|c|c|}
\hline Variables & Definition & Data Sources \\
\hline Public Debt & $\begin{array}{l}\text { The dependent variable of the study is public debt, which is } \\
\text { proxied by general government gross debt. The International } \\
\text { Monetary Fund defines general government gross debt as all } \\
\text { liabilities requiring refund of principal and interest from the debtor } \\
\text { to the lender at a future date. }\end{array}$ & $\begin{array}{c}\text { World Economic Outlook } \\
\text { database (2000-2018) }\end{array}$ \\
\hline Corruption & $\begin{array}{l}\text { Control of corruption measures the rate at which public officials } \\
\text { exercise public power for personal gains. It includes both petty and } \\
\text { grand forms of corruption. It also measures the ability of state } \\
\text { policies and institutions to fight and prevent corruption. There are } \\
\text { other corruption measures such as the International Country Risk } \\
\text { Guide and the Transparency International Corruption Index. } \\
\text { Corruption data from Kaufmann et al. (2013) ranges from - } 2.5 \\
\text { (totally corrupt) to } 2.5 \text { (no corruption). }\end{array}$ & $\begin{array}{l}\text { Worldwide Governance } \\
\text { Indicators database } \\
\quad(2000-2018)\end{array}$ \\
\hline Government Investment & $\begin{array}{l}\text { Government investment is proxied by gross capital formation in } \\
\text { this study. Gross capital formation consists of additions to the land } \\
\text { improvements, plant, machinery and equipment purchases; and the } \\
\text { construction of roads, railways and many others according to the } \\
\text { World Bank definition. }\end{array}$ & $\begin{array}{l}\text { World Development } \\
\text { Indicators database } \\
\qquad(2000-2018)\end{array}$ \\
\hline Government Consumption & $\begin{array}{c}\text { Government consumption, which is proxied by general } \\
\text { government final consumption, is defined by the World Bank to } \\
\text { include all government current expenditures for purchases of } \\
\text { goods and services (including compensation of employees in the } \\
\text { form of wage and salaries). This variable is measured as a } \\
\text { percentage of GDP }\end{array}$ & $\begin{array}{l}\text { World Development } \\
\text { Indicators database } \\
\qquad(2000-2018)\end{array}$ \\
\hline Military Expenditure & $\begin{array}{l}\text { Military spending is defined as all current and capital expenditures } \\
\text { on the military, including peacekeeping forces. It is proxied by } \\
\text { military expenditure measured as a percentage of GDP. }\end{array}$ & $\begin{array}{l}\text { World Development } \\
\text { Indicators database } \\
\quad(2000-2018)\end{array}$ \\
\hline
\end{tabular}


Table 1. Cont.

\begin{tabular}{|c|c|c|}
\hline Variables & Definition & Data Sources \\
\hline Tax Revenue & $\begin{array}{l}\text { Tax revenue relates to mandatory transfers to the central } \\
\text { government for public purposes. Some mandatory transfers, such } \\
\text { as fines, penalties and most social security contributions are } \\
\text { excluded. Refunds and corrections of incorrectly collected tax } \\
\text { revenue are considered negative revenue. }\end{array}$ & $\begin{array}{l}\text { World Development } \\
\text { Indicators database } \\
\qquad(2000-2018)\end{array}$ \\
\hline Gross Domestic Product & $\begin{array}{l}\text { Economic growth is proxied by GDP per capita measured in } \\
\text { constant } 2010 \text { US\$. }\end{array}$ & $\begin{array}{l}\text { World Development } \\
\text { Indicators database } \\
\quad(2000-2018)\end{array}$ \\
\hline Exchange Rate & Exchange rate is proxied by national currency per US dollar. & $\begin{array}{l}\text { World Development } \\
\text { Indicators database } \\
\quad(2000-2018)\end{array}$ \\
\hline Inflation & The annual percentage $(\%)$ change in the consumer price index & $\begin{array}{c}\text { Competitiveness Index Report } \\
\text { (2000-2018) }\end{array}$ \\
\hline
\end{tabular}

Authors' own computations sourced from the World Bank World Development Indicators (WDI), World Competitiveness Index report, Worldwide Governance Indicators database and World Economic Outlook database (2000-2018).

\subsection{Baseline Model Specification}

Panel data as defined by Arellano and Bond [48] as the pooling of observations on a cross-section of units of observation over a period. This overcomes some limitations of using strictly cross-sectional or time series data [48-50].

Because of our formulated research questions and the construction of African countries, a functional model was specified with gross government debt which proxies public debt and the determining drivers that impact the level of public debt in Africa. In addition, to avoid the problem of misspecification of the model, several variables were deemed fit to influence public debt levels. Thus, our model is as follows:

$$
\begin{gathered}
P B D T_{i t}=\beta_{0}+\beta_{1}(C O R R)_{i t}+\beta_{2}(\text { GOVIN })_{i t}+\beta_{3}(G O V C)_{i t}+\beta_{4}(M E X)_{i t} \\
+\beta_{5}(\text { TAXR })_{i t} \beta_{5}(\text { Control Var })_{i t}+\varepsilon_{i t}
\end{gathered}
$$

The variables are defined below:

$i$-selected countries of observation: Algeria, Botswana, Gambia, Morocco, etc. $t$ period of observation: 2000, 2011, .. 2018. $\beta_{0}$-Intercept. PBDT $i t$-Public Debt. CORR $i t$ Level of Corruption. GOVIN ${ }_{i t}$-Government Investment. GOVC $i t$-Government Consumption. $M E X_{i t}$-Military Expenditure. TAXR $R_{i t}$ - Tax Revenues Control Var ${ }_{i t}$-a vector of control variable. $\varepsilon_{i t}$-error/disturbance term.

Our study adopted panel data since it sought to study different nations in Africa. The model used the dynamic generalized methods of moments (GMM) evolved via Arellano and Bond [48,49]. The choice to apply the dynamic panel estimator was made to correct simultaneity bias and other precise nation effects with the aid of transforming the version to the first distinction eliminating country-specific outcomes [48]. There are two ways to estimate GMMs, one-step GMM estimation and two-step GMM estimation. A two-step estimate with corrected standard errors was accepted for this study. The two-step GMM estimate has also been used because it controls endogeneity and is more suitable for long periods and many observations [48-50]. The Hansen J test and the Arellano and Bond test were performed to ensure the accuracy of the estimates $[48,49]$. The validity of the instruments and the suitability of the model were also tested using the Hansen J test. The robustness of our results was done to overcome any possible endogeneity of our sampled data: we adopted Fixed effect two-stage least squares (IV-FE). This approach was adopted because of endogeneity problems arising from reverse causality between public debt and government investment [21,51]. Additional variables such as government expenditure would be added to the baseline specification and checked if our results remained unchanged. 


\section{Empirical Results and Discussion}

Table 2 suggests the descriptive analysis of our study. The table indicates the number of observations, the mean, the minimum observations, and the standard deviations for each variable. The mean recorded for the public debt to GDP ratio is 60.77. On average, the sampled countries recorded 1.05 for corruption. Government investment recorded a mean of 22.96, with minimum and maximum values of 1.09 and 61.46, respectively. Government consumption and military expenditure recorded averages of 15.23 and 1.82, respectively. Revenue from tax on average was 16.69 , with minimum and maximum values of 4.10 and 39.99, respectively. Moreover, the descriptive statistics indicate significant variability in the key variables across the countries in the data set as depicted by the standard deviation values.

Table 2. Descriptive statistics of variables (2000-2018).

\begin{tabular}{cccccc}
\hline Variable & Obs & Mean & Std. Dev. & Min & Max \\
\hline Public debt & 877 & 60.773 & 52.688 & 5.513 & 514.916 \\
Corruption & 893 & 1.05 & 0.417 & 0 & 1.946 \\
Government investment & 850 & 22.961 & 9.483 & 1.097 & 61.469 \\
Government consumption & 844 & 15.239 & 7.531 & 0.952 & 73.577 \\
Military expenditure & 805 & 1.816 & 1.203 & 0.146 & 7.956 \\
Tax revenue & 419 & 16.689 & 7.397 & 4.099 & 39.988 \\
Gross domestic product & 893 & 2146.934 & 2560.977 & 194.873 & 14385.3 \\
Exchange rate & 847 & 467.099 & 785.404 & 0.545 & 7384.43 \\
Inflation & 827 & 99.734 & 42.67 & 0 & 382.501 \\
\hline
\end{tabular}

Source: Authors' own calculation, 2021.

\subsection{GMM Results}

Table 3 below suggests and discusses the results of our empirical estimates. As already referred to, our outcomes had been based on the key drivers of public debt levels in Africa and for that reason assist us to answer our formulated questions via the dynamic panel generated model of moments (GMM). It should be cited that the number of observations in Tables 2 and 3 is different as the extreme values had been disregarded from regression analysis as explained by Arellano and Bover [48]. The missing variables in the model debate have been explained and summarized in [51].

Based on our GMM regression (Table 3), the coefficient of corruption recorded a positive and statistically significant relationship with the public debt level in Africa. The existence of corruption reduces government revenue generation from private sector organizations. Corrupt public officials take bribes from private firms to cover up their reluctance to pay taxes. Thus, this affects the productivity of state-owned businesses because of misplacement of talents. This finding is consistent with $[13,29,52,53]$ and supports the answer to our first research question: corruption has a strong impact on public debt levels in Africa.

The positive and strong significant association between government investment and public debt levels shows that insufficient revenue mobilization of most African countries leads to governments borrowing to fund infrastructural projects such as road construction, railway construction, and building schools and hospitals, among others, leading to public debt accumulation. In Africa, the involvement of private individuals in providing capital formation is minimal. The government, therefore, absorbs huge infrastructural investment costs from road construction, railway construction, and building schools and hospitals and other capital expenditures in the economy, requiring the government to incur more debt. Thus, our outcome affirms our second research question on whether government investment contributes to the increasing levels of public debt in Africa. Our results were consistent with the previous studies of [8,31,43-45].

Furthermore, government consumption has a significant negative relationship with the levels of public debt in Africa. The result shows that government consumption decreases the level of public debt in Africa. This result is not surprising because, as government 
ensures good conditions of service to public officials by paying wages and salaries regularly and equipping public workers with the necessary resources that facilitate work, the overall productivity of the public sector improves which reflects on revenue generation of the government. Thus, our outcome affirms our subsequent research question on whether government consumption is a determining factor of public debt levels in Africa. Our outcome was predictable based on earlier studies by [31,35,44,53-61].

Moreover, contrary to our expectations, our results showed that military expenditure has a positive but insignificant relationship with public debt levels in Africa. This finding contradicts the findings of [37-40], that military spending increases public debt levels. The contradiction can be explained by jurisdiction differences. The above studies were conducted in Middle East countries that are noted to deal more in arms purchasing and military equipment buying because of persistent conflict outbreaks within the area. As a result, military expenditure contributes significantly to increasing public debt levels in that part of the world. However, in Africa, though military expenses are incurred, military expenditure is not a key driver of government debt level. This outcome answers our fourth research question, that military expenditure is not a driver of public debt levels in African countries.

In addition to this, our results revealed that tax revenue and the level of public debt in Africa has a negative but strong relationship. As such, African economies have been noted for striving for a balanced policy approach to achieving growth and development through tax revenue. This, in turn, will reduce the public debt level in Africa. Thus, our result affirms our research question that tax revenue has an impact on the public debt level in Africa. Our result was consistent with earlier studies by [13,20,41,47,55-57].

Lastly, our control variable, gross domestic product (GDP), has a negative and significant relationship with public debt. The estimated value of GDP growth is significant at any of the conventional significance levels. This signifies that, as a country improves on its domestic production of goods and services, it can generate more revenue leading to less borrowing. This finding is consistent with the findings of $[15,23,31-33,58]$ that economic growth reduces the level of public debt. The study found no noteworthy relationship between exchange rate and inflation with public debt, contradicting the findings of $[25,59]$ who found that exchange rate is a key determinant of public debt. The reason for this contradiction may be that most African countries rely more on domestic debt than external debt.

Table 3. IV GMM System Regression Results.

\begin{tabular}{|c|c|c|c|c|c|c|c|}
\hline Public Debt & Coef. & St.Err. & $t$-Value & $p$-Value & $95 \%$ Conf & Interval & Sig \\
\hline Corruption & 49.868 & 11.125 & 4.48 & 0.000 & 71.672 & 28.065 & $* * *$ \\
\hline Government consumption & -0.64 & 0.103 & -6.23 & 0.000 & -0.439 & -0.842 & $* * *$ \\
\hline Government investment & 1.225 & 0.072 & 17.13 & 0.000 & 1.365 & 1.085 & $* * *$ \\
\hline Military expenditure & 4.84 & 1.662 & 2.91 & 0.134 & 1.582 & 8.098 & \\
\hline Tax revenue & -1.251 & 0.213 & -5.89 & 0.000 & -1.668 & -0.834 & $* * *$ \\
\hline Gross domestic product & -0.015 & 0.005 & -3.04 & 0.002 & -.025 & -0.005 & $* * *$ \\
\hline Exchange rate & 0.011 & 0.003 & 4.20 & 0.286 & .006 & 0.016 & \\
\hline Inflation & 0.025 & 0.016 & 1.52 & 0.129 & -.007 & 0.056 & \\
\hline Constant & 171.711 & 10.11 & 16.98 & 0 & 151.895 & 191.527 & $* * *$ \\
\hline Mean dependent var & \multicolumn{2}{|c|}{60.773} & \multicolumn{3}{|c|}{ SD dependent var } & \multicolumn{2}{|c|}{52.688} \\
\hline Number of observations & \multicolumn{2}{|c|}{422} & \multicolumn{3}{|c|}{ Chi-square } & \multicolumn{2}{|c|}{2549.614} \\
\hline Hansen J-Statistics & \multicolumn{2}{|c|}{2.051} & \multicolumn{3}{|c|}{ Prob $>$ chi2 } & \multicolumn{2}{|c|}{0.0000} \\
\hline$p$-value & \multicolumn{2}{|c|}{0.000} & \multicolumn{3}{|c|}{ Arellano-Bond Test (2) } & \multicolumn{2}{|c|}{0.2910} \\
\hline
\end{tabular}

Notes: The values in parentheses are the $p$-values denoted by ${ }^{* * *}$ representing $1 \%$ significant levels. Authors' own calculation, 2021. 


\subsection{Robustness Check}

To undertake a robustness check, we added an additional variable called government expenditure which also has an impact on the level of public debt in Africa to the baseline specification and checked if our results would remain unchanged. Table 4 shows that by employing fixed effect two stage least squares (IV-FE). Again, the result from fixed effect two-stage least squares (IV-FE) does not differ significantly from our dynamic panel generated model of moments (GMM). This approach was adopted because of endogeneity problems arising from reverse causality between public debt and government investment $[31,55,60]$.

Table 4. Fixed effect two stage least squares (IV-FE) estimation.

\begin{tabular}{|c|c|}
\hline IV & $(2)$ \\
\hline & public debt \\
\hline \multirow[t]{2}{*}{ Corruption } & $0.208^{* * *}$ \\
\hline & $(0.046)$ \\
\hline \multirow[t]{2}{*}{ Government expenditure } & $0.393^{* * *}$ \\
\hline & $(0.001)$ \\
\hline \multirow[t]{2}{*}{ Government consumption } & $-0.108^{* *}$ \\
\hline & $(0.0512)$ \\
\hline \multirow[t]{2}{*}{ Government investment } & $0.390^{* *}$ \\
\hline & $(0.0801)$ \\
\hline \multirow[t]{2}{*}{ Tax revenue } & -0.302 \\
\hline & $(0.312)$ \\
\hline \multirow[t]{2}{*}{ inflation } & 0.0867 \\
\hline & $(0.257)$ \\
\hline \multirow[t]{2}{*}{ Military expenditure } & 1.769 \\
\hline & $(1.692)$ \\
\hline \multirow[t]{2}{*}{ Exchange rate } & 0.286 \\
\hline & $(0.00611)$ \\
\hline Gross domestic product & $-0.00310^{* * *}$ \\
\hline Observation & 386 \\
\hline Hansen-j statistic & 1.616 \\
\hline$p$-value & {$[0.446]$} \\
\hline Anderson test statistic & 370.2 \\
\hline$p$-value & {$[0.000]$} \\
\hline Cragg Donald F-statistic & 157.0 \\
\hline
\end{tabular}

Notes: The values in parentheses are the $p$-values denoted by ${ }^{* * *}$ and ${ }^{* *}$ representing $1 \%$, and $5 \%$ significant levels, respectively. Authors' own calculation, 2021.

\section{Conclusions and Recommendations}

Several questions on the issue of public debt level management, drivers of public debt and debt sustainability in Africa have been raised by the International Monetary Fund (IMF) and the World Bank with other bilateral organizations. The results of about thirty-three (33) countries in Africa that have been declared as Highly Indebted Poor Countries (HIPC) and had to be relieved of their debt by these organizations [21,22]. The factsheet by the IMF shows that African countries could not achieve most of their MDGs even after the debt relief packages [28]. Our study comes in time to address the threshold impact of the key drivers of public debt levels of African countries in order to avoid unnecessary austerity 
measures that could be detrimental to African economies. The aim of our paper was to investigate the key determining drivers that have a direct and indirect impact on the public debt levels in Africa via estimation of the dynamic panel generated model of moments (GMM) and fixed effect two-stage least squares (IV-FE) for our model. We carried out this research on forty-seven (47) African nations from 2000-2018.

Our empirical model strived to forecast whether the level of public debt is influenced by corruption, government investment, government consumption, military expenditure and tax revenue. Our model controlled other variables such as gross domestic product, exchange rate and inflation. Our findings arrived at the following conclusions

First, there is a statistically positive relationship between corruption and public debt level in African countries. Empirically speaking, the increasing level of corruption in African countries fosters the public debt level into rising. Second, the strong significant association between government investment and public debt level shows that insufficient revenue mobilization of most African countries leads to governments borrowing to fund infrastructural projects such as road construction, railway construction, and building schools and hospitals, among others, leading to public debt accumulation. Third, our results revealed that government consumption has a significant negative relationship with the levels of public debt in Africa. This result is not surprising because, as governments ensure good conditions of service to public officials by paying wages and salaries regularly and equipping public workers with the necessary resource that facilitate work, the overall productivity of the public sector improves, which reflects on the revenue generation of the government. Furthermore, our results showed that military expenditure has a positive but insignificant relationship with public debt levels in Africa, contrary to our expectation. The contradiction can be explained by jurisdiction differences. Prior studies were conducted in countries in the Middle East that are noted to deal more in arms purchasing and military equipment buying because of persistent conflict outbreaks within the area. As a result, military expenditure contributes significantly to increasing public debt levels in that part of the world. However, in Africa, though military expenses are incurred, military expenditure is not a key driver of government debt levels. Moreover, our results revealed that tax revenue and the level of public debt in Africa have a negative but strong relationship. As such, African economies have been noted for striving for a balanced policy approach to achieving growth and development through tax revenue. In addition to this, gross domestic product has a negative and significant relationship with public debt. This signifies that, as a country improves on its domestic production of goods and services, it can generate more revenue, leading to less borrowing. Inflation and exchange rate had no significant relationship with the level of public debt in Africa.

Considering the drivers behind the rising level of public debt in African nations, our paper also recommended some relevant policy implications. First, African economies seeking to reduce the level of public debt should strive to fight against corruption. Second, strengthening political and governance institutions will generally diminish corruption in an economy. Lastly, another way to reduce public debt in Africa is through the restructuring of government spending from corruption-prone investments to the ones that can be properly managed and monitored. This would aid African countries' fight in opposition to poverty.

Our study had few barriers which must be dealt with to improve future studies in this region. The first predicament was a lack of long-term longitudinal information of all fifty-four African countries as indicated by the United Nations. This difficulty has been a common issue with many studies on growing African countries, which highlights the need for more data on these economies. Future research can look at the non-linear relationship between corruption and public debt of individual countries in Africa.

Author Contributions: Conceptualization, S.N.K.A.-K., K.M. (Karel Malec), and M.M.; methodology, S.N.K.A.-K., K.M. (Karel Malec), and J.P.; software, S.N.K.A.-K., J.P., K.M. (Kamil Maitah), and M.K.; validation, S.N.K.A.-K., K.M. (Karel Malec), M.M., L.S., and J.P.; formal analysis, S.N.K.A.-K., K.M. (Karel Malec), S.N.K.A.-K., and M.M.; investigation, S.N.K.A.-K., M.M., K.M. (Karel Malec), and M.K.; resources, S.N.K.A.-K., K.M. (Karel Malec), J.P., and L.S.; data curation, S.N.K.A.-K., K.M. 
(Karel Malec), K.M. (Kamil Maitah), and J.P.; writing—original draft preparation, K.M. (Karel Malec), M.M., and S.N.K.A.-K.; writing-review and editing, S.N.K.A.-K., K.M. (Karel Malec), and M.M.; visualization, S.N.K.A.-K., K.M. (Karel Malec), M.M., K.M. (Kamil Maitah), and J.P.; supervision, M.M., and L.S.; project administration, K.M. (Karel Malec), S.N.K.A.-K., and M.M.; funding acquisition, S.N.K.A.-K., K.M. (Karel Malec), M.M., and L.S. All authors have read and agreed to the published version of the manuscript.

Funding: This paper was supported by the Project no. 52/2021 “AN ASSESSMENT OF THE ROLE OF INSTITUTIONS IN ENABLING DEVELOPMENT IN AFRICA “, financed from the OP RDE project Improvement in Quality of the Internal Grant Scheme at Czech University of Life Sciences Prague, reg. no. CZ.02.2.69/0.0/0.0/19_073/0016944.

Data Availability Statement: Not applicable.

Acknowledgments: We would like to thank the OP RDE project Improvement in Quality of the Internal Grant Scheme at Czech University of Life Sciences Prague, reg. no. CZ.02.2.69/0.0/0.0/19_073/0016944 for providing support and funding for this project and a special dedication to my beloved mom Gifty Giver Fofie and the whole Fofie family in Ghana.

Conflicts of Interest: The authors declare no conflict of interest.

\section{References}

1. Bokpin, G.A.; Mensah, L.; Asamoah, M.E. Legal source, institutional quality and FDI flows in Africa. Int. J. Law Manag. 2017, 59, 687-698. [CrossRef]

2. $\quad$ Appiah-Kubi, S.N.K.; Malec, K.; Maitah, M.; Kutin, S.B.; Pánková, L.; Phiri, J.; Zaganjori, O. The impact of corporate governance structures on foreign direct investment: A case study of West African countries. Sustainability 2020, 12, 3715. [CrossRef]

3. Kirkpatrick, C.; Parker, D.; Zhang, Y.F. Foreign direct investment in infrastructure in developing countries: Does regulation make a difference? Transnatl. Corp. 2006, 15, 143-171.

4. McLean, R.D.; Zhang, T.; Zhao, M. Why does the law matter? Investor protection and its effects on investment, finance, and growth. J. Financ. 2012, 67, 313-350. [CrossRef]

5. Saini, N.; Singhania, M. Determinants of FDI in developed and developing countries: A quantitative analysis using GMM. J. Econ. Stud. 2018, 45, 348-382. [CrossRef]

6. Fan, S.; Omilola, B.; Lambert, M. Public spending for agriculture in Africa: Trends and composition. Reg. Strateg. Anal. Knowl. Support Syst. 2009, 5 .

7. Serven, L.; Solimano, A. Debt crisis, adjustment policies and capital formation in developing countries: Where do we stand? World Dev. 1993, 21, 127-140. [CrossRef]

8. Mah, G.; Mukkudem-Petersen, J.; Miruka, C.; Petersen, M.A. The impact of government expenditure on the Greek government debt: An econometric analysis. Mediterr. J. Soc. Sci. 2013, 4, 323. [CrossRef]

9. Maana, I.; Owino, R.; Mutai, N. Domestic debt and its impact on the economy-The case of Kenya. In Proceedings of the 13th Annual African Econometric Society Conference in Pretoria, Pretoria, South Africa, 9-11 July 2008; Volume 40.

10. Prichard, W.; Cobham, A.; Goodall, A. The ICTD Government Revenue Dataset. ICTD Working Paper 19. 1 September 2014. Available online: https:/ / ssrn.com/abstract=2496442 or http:/ / dx.doi.org/10.2139/ssrn.2496442 (accessed on 20 January 2021).

11. Castro, C.; Nunes, P. Does corruption inhibit foreign direct investment? Política. Rev. Cienc. Política 2013, 51, 61-83. [CrossRef]

12. Burhanudin, M.D.A.; Muda, R.; Nathan, S.B.S.; Arshad, R. Real effects of /government debt on sustainable economic growth in Malaysia. J. Int. Stud. 2017, 10. [CrossRef] [PubMed]

13. Cooray, A.; Dzhumashev, R.; Schneider, F. How does corruption affect public debt? An empirical analysis. World Dev. 2017, 90, 115-127. [CrossRef]

14. Anyanwu, J.C. Characteristics and macroeconomic determinants of youth employment in Africa. Afr. Dev. Rev. 2013, 25, 107-129. [CrossRef]

15. Omrane Belguith, S.; Omrane, H. Macroeconomic determinants of public debt growth: A case study for Tunisia. Theor. Appl. Econ. 2017, 24, 161-168.

16. Appiah-Kubi, S.N.K.; Malec, K.; Phiri, J.; Maitah, M.; Gebeltová, Z.; Smutka, L.; Blazek, V.; Maitah, K.; Sirohi, J. Impact of Tax Incentives on Foreign Direct Investment: Evidence from Africa. Sustainability 2021, 13, 8661. [CrossRef]

17. Greene, J.; Villanueva, D. Private investment in developing countries: An empirical analysis. Staff. Pap. 1991, 38, 33-58. [CrossRef]

18. Elbadawi, I.A.; Ndulu, J.B.; Ndungu, N. Debt Overhang Andeconomic Growth in Sub-saharan Africa. In External Finance for Low-Income Countries; Iqbal, Z., Kanbur, R., Eds.; International Monetary Fund: Washington, DC, USA, 1997.

19. Cunningham, R.T. The effects of debt burden on economic growth in heavily indebted developing nations. J. Econ. Dev. 1993, 18, 115-126. Available online: http:/ / www.jed.or.kr/full-text/18-1/5.pdf (accessed on 20 January 2021).

20. Mensah, L.; Allotey, D.; Sarpong-Kumankoma, E.; Coffie, W. What debt threshold hampers economic growth in Africa? Int. J. Dev. Issues 2019, 19, 25-42. [CrossRef] 
21. Ndoricimpa, A. Threshold effects of public debt on economic growth in Africa: A new evidence. J. Econ. Dev. 2020, 22, 187-207. [CrossRef]

22. Deshpande, A. The debt overhang and the disincentive to invest. J. Dev. Econ. 1997, 52, 169-187. [CrossRef]

23. Pirtea, M.G.; Nicolescu, A.C. An empirical study on public debt's determinants: Evidence from Romania. Transylv. Rev. Adm. Sci. 2013, 9, 144-157.

24. Rohwer, A. Measuring Corruption: A Comparison between the Transparency International's Corruption Perceptions Index and the World Bank's Worldwide Governance Indicators. CESifo DICE Rep. 2009, 7, 42-52. Available online: https://www.econstor. $\mathrm{eu} / \mathrm{handle} / 10419 / 166975$ (accessed on 27 May 2021).

25. Imimole, B.; Imoughele, L.E.; Okhuese, M.A. Determinants and sustainability of external debt in a deregulated economy: A cointegration analysis from Nigeria (1986-2010). Am. Int. J. Contemp. Res. 2014, 4, 201-214.

26. Ncanywa, T.; Masoga, M.M. Can public debt stimulate public investment and economic growth in South Africa? Cogent Econ. Financ. 2018, 6, 1516483. [CrossRef]

27. Maitah, M.; Soleimani, D.; Malec, K.; Kobzev Kotásková, S. Foreign direct investments and gross domestic product development in USA, European Union, and China (1995-2014). Int. J. Econ. Financ. Issues 2016, 6, 978-984.

28. Transparency International. Global Corruption Report; Taylor \& Francis Routledge: London, UK, 2016; pp. 1-368. [CrossRef]

29. Apergis, E.; Apergis, N. New evidence on corruption and government debt from a global country panel: A non-linear panel long-run approach. J. Econ. Stud. 2019, 46, 1009-1027. [CrossRef]

30. Hannes, B. A failure of governmentality: Why Transparency International underestimated corruption in Ben Ali's Tunisia. Third World Q. 2017, 38, 467-482. [CrossRef]

31. Swamy, V. Government Debt and Its Macroeconomic Determinants-An Empirical Investigation. 2 May 2015. Available online: https:/ / ssrn.com/abstract=2601875 or http:/ / dx.doi.org/10.2139/ssrn.2601875 (accessed on 20 January 2021).

32. Julio, B.; Yook, Y. Policy uncertainty, irreversibility, and cross-border flows of capital. J. Int. Econ. 2016, 103, 13-26. [CrossRef]

33. Batool, S.A.; Zulfiqar, S. What determines external debt? Empirical evidence from Pakistan. Bus. Manag. Rev. 2015, 3, 263. Available online: https:/ / www.proquest.com/openview/08a06ca5ac4141856bcfed57423daaac/1?cbl=2026610\&pq-origsite= gscholar\&accountid=26997 (accessed on 20 January 2021).

34. Liu, C.; Mikesell, J.L. The impact of public officials' corruption on the size and allocation of US state spending. Public Adm. Rev. 2014, 74, 346-359. [CrossRef]

35. Al-Qudah, A.M. Macroeconomic Factors and Public Debt: Empirical Evidence from Jordan. Int. J. Bus. Soc. Sci. 2019, 10. [CrossRef]

36. Smyth, R.; Kumar Narayan, P. A panel data analysis of the military expenditure-external debt nexus: Evidence from six Middle Eastern countries. J. Peace Res. 2009, 46, 235-250. [CrossRef]

37. Paleologou, S.M. A Dynamic Panel Data Model for analyzing the relationship between military expenditure and government debt in the EU. Def. Peace Econ. 2013, 24, 419-428. [CrossRef]

38. Gargouri, I.; Keantini, M. The determinants of public debt. Rom. Econ. J. 2016, XVIII. Available online: http:/ / www.rejournal.eu/ sites/rejournal.versatech.ro/files/articole/201603-30/3346/7majdiksantini.Pdf (accessed on 20 January 2021).

39. Caruso, R.; Di Domizio, M. Military spending and budget deficits: The impact of US military spending on public debt in Europe (1988-2013). Def. Peace Econ. 2017, 28, 534-549. [CrossRef]

40. Cooray, A.; Schneider, F. Does corruption promote emigration? An empirical examination. J. Popul. Econ. 2016, 29, 293-310. [CrossRef]

41. Shleifer, A.; Vishny, R.W. Corruption. Q. J. Econ. 1993, 108, 599-617. [CrossRef]

42. Waheed, A. Determinants of External Debt: A Panel Data Analysis for Oil \& Gas Exporting and Importing Countries. Int. J. Econ. Financ. Issues 2017, 7. Available online: https: / /www.proquest.com/docview $/ 1865227013$ ?pqorigsite=gscholar\&fromopenview= true (accessed on 20 January 2021).

43. Bittencourt, M. Determinants of government and external debt: Evidence from the young democracies of South America. Emerg. Mark. Financ. Trade 2015, 51, 463-472. [CrossRef]

44. Sinha, P.; Arora, V.; Bansal, V. Determinants of Public Debt for middle income and high income group countries using Panel Data regression. Munich Pers. RePEc Arch. 2011. Available online: https:/ /mpra.ub.uni-muenchen.de/32079/ (accessed on 20 January 2021).

45. Gokmenoglu, K.; Rafik, R.A.M. Determinants of External Debt: The Case of Malaysia. In Emerging Trends in Banking and Finance; Springer: Cham, Switzerland, 2018; pp. 16-33. Available online: https://link.springer.com/chapter/10.1007/978-3-030-01784-2_2 (accessed on 20 January 2021).

46. Méon, P.G.; Sekkat, K. Does the quality of Institutions Limit the MENA's integration in the World Economy. World Econ.-Glob. Trade Policy 2005, 27, 155-178. Available online: https:/ /books.google.dk/books?hl=en\&lr=\&id=93Qp3C8nDy4C\&oi=fnd\&pg= PA155\&dq (accessed on 20 January 2021). [CrossRef]

47. Jackson, M.; Kirby, E.; Smith, R.; Thompson, L. Sovereign eyes: Legislators' perceptions of corruption. J. Commonw. Comp. Politics 1994, 32, 54-67. [CrossRef]

48. Arellano, M.; Bond, S. Some Tests of Specification for Panel Data: Monte Carlo Evidence and an Application to Employment Equations. Rev. Econ. Stud. 1991, 58, 277. [CrossRef] 
49. Arellano, M.; Bover, O. Another look at the instrumental variable estimation of error-components models. J. Econ. 1995, 68, 29-51. [CrossRef]

50. Baltagi, B.H.; Liu, L. Estimation and prediction in the random effects model with $\mathrm{AR}(p)$ remainder disturbances. Int. J. Forecast. 2013, 29, 100-107. [CrossRef]

51. Barrell, R.; Nahhas, A. Economic Integration and Bilateral FDI Stocks: The Impacts of NAFTA and the EU; LSE Research Online Documents on Economics 90372; London School of Economics and Political Science, LSE Library: London, UK, 2018; Volume 14, pp. 7-9. Available online: https:/ /EconPapers.repec.org/RePEc:ehl:lserod:90372 (accessed on 15 April 2021).

52. González-Fernández, M.; González-Velasco, C. Shadow economy, corruption and public debt in Spain. J. Policy Modeling 2016, 36, 1101-1117. [CrossRef]

53. Benfratello, L.; Del Monte, A.; Pennacchio, L. Corruption and public debt: A cross-country analysis. Appl. Econ. Lett. 2018, 25, 340-344. [CrossRef]

54. Del Monte, A.; Papagni, E. Public expenditure, corruption, and economic growth: The case of Italy. Eur. J. Political Econ. 2001, 17, 1-16. [CrossRef]

55. Appiah-Kubi, S.N.K.; Mansoor, M.; Zaganjori, O.; Sahatqija, O.; Malec, K. The Impact of Macroeconomics variables on the inflows of FDI in the least Developed West African Countries. In Agrarian Perspectives XXVII, Business Scale in Relation to Economics; Czech University of Life Sciences Prague: Prague, Czech Republic, 2019; Volume XXVII, pp. 7-13, ISBN 978-80-213-2973-7.

56. Lambsdorff, J.G. Causes and consequences of corruption: What do we know from a cross-section of countries. Int. Handb. Econ. Corrupt. 2006, 1, 3-51. Available online: https://books.google.cz/books?hl=en\&lr=\&id=P60nm (accessed on 20 January 2021).

57. Malec, K.; Gouda, S.; Kuzmenko, E.; Soleimani, D.; Řezbová, H.; Šánová, P. Gross Domestic Product Development and Employment in Egypt (2000-2013). Int. J. Econ. Financ. Issues 2016, 6, 199-206.

58. Peters, G.T.; Kiabel, B.D. Tax incentives and foreign direct investment in Nigeria. IOSR J. Econ. Financ. 2015, 6, 10-20.

59. Tuomi, K. The Role of the Investment Climate and Tax Incentives in the Foreign Direct Investment Decision: Evidence from South Africa. J. Afr. Bus. 2011, 12, 133-147. [CrossRef]

60. Etim, R.S.; Jeremiah, M.S.; Jeremiah, O.O. Attracting foreign direct investment (FDI) in Nigeria through effective tax policy incentives. Int. J. Appl. Econ. Financ. Account. 2019, 4, 36-44. [CrossRef]

61. Maitah, M.; Saleem, N.; Malec, K.; Boubaker, M.; Gouda, S. Economic value added and stock market development in Egypt. Asian Soc. Sci. 2015, 11, 126. [CrossRef] 